\title{
HUBUNGAN FASILITAS SANITASI DAN KUALITAS JASA DENGAN TINGKAT KEPUASAN PENGUNJUNG TAHURA NGURAH RAI PROVINSI BALI
}

\author{
Ni Made Parthin Puti Purwaningrum', I Wayan Suarta Asmara²
}

\begin{abstract}
Ngurah Rai Forest Park is one of the public recreation places with ecotourism objects that can attract visitors. The purpose of this study was to determine the correlation of sanitation facilities and service quality with level of visitor satisfaction of Ngurah Rai Forest Park At Bali Province. Research used is quantitative with a crossectional approach survey method. The sample used was 100 out of 1,323 populations using quota sampling. Based on the chi-square test results, it is obtained that sanitation facilities with sig $=0.045<(0.05)$, means there is a significant correlation sanitation facilities with the visitore satisfaction level with $C C=0.237$, which means that the level of correlation is low, while service quality with visitor satisfaction level is obtained sig $=0,000<0.05$ means that there is a significant correlation of service quality and level of visitor satisfaction with $C C=0.543$ means the level of correlation is medium. The conclusion of this research is that there is a correlation between sanitation facilities and service quality with the level of satisfaction of visitors of Ngurah Rai Forest Park at Bali Province. The advice is to improve the quality of services and sanitation facilities to increase visitor satisfaction.
\end{abstract}

Keywords: sanitation facilities, service quality, level of visitor satisfaction

\section{Pendahuluan}

Provinsi Bali memiliki satu satunya tahura yaitu Taman Hutan Raya Ngurah Rai Provinsi Bali yang terletak di kawasan strategis pariwisata, yang teletak di kawasan wisata utama yaitu Sanur, Kuta, dan Nusa Dua yang tentunya akan banyak dikunjungi oleh wisatawan domestik dan mancanegara

Penelitian yang dilakukan oleh Pastin M (2014) mengenai Tingkat Kepuasan Masyarakat Terhadap Kualitas Jasa Taman Hutan Raya Ngurah Rai Provinsi Bali, didapatkan hasil bahwa rata - rata presentase tingkat kepuasan pengunjung mencapai $67,68 \%$ yang berada dalam kategori cukup memuaskan, dimana penelitian tersebut menilai kualitas jasa dengan 5 dimensi (1). Namun dalam penelitian tersebut belum meneliti hubungan fasilitas sanitasi dan kualitas jasa dengan tingkat kepuasan pengunjung Taman Hutan Raya Ngurah Rai Provinsi Bali.

Berdasarkan hal tersebut peneliti tertarik untuk mengadakan penelitian mengenai hubungan fasilitas sanitasi dan kualitas jasa dengan tingkat 
kepuasan pengunjung Taman Hutan kepuasan pengunjung Taman Hutan Raya Ngurah Rai Provinsi Bali.

Raya Ngurah Rai Provinsi Bali.

Tujuan dari penelitian ini untuk

Manfaat penelitian ini adalah mengetahui hubungan fasilitas sanitasi untuk memberikan informasi, dan kualitas jasa dengan tingkat menambah wawasan dan meningkatan partisipasi dalam melestarikan Rai Provinsi Bali, besar sampel yang kawasan Taman Hutan Raya Ngurah digunakan yaitu 100 responden Rai Provinsi Bali.

\section{Metode}

Jenis penelitian ini termasuk .Teknik sampling yang digunakan yaitu sampling quota. Pengumpulan data menggunakan kuesioner yang penelitian kuantitatif dengan dijawab oleh responden. Data yang rancangan metode survey dan terkumpul di analisis menggunakan pendekatan cross sectional. uji Chi Square $\left(X^{2}\right)$. Untuk Responden dalam penelitian ini mengetahui besarnya hubungan dapat adalah pengunjung Tahura Ngurah menggunakan Coeffient Contingency (CC) 


\section{Hasil dan Pembahasan}

Berdasarkan penelitian yang telah dilakukan, maka diperoleh hasil sebagai berikut :

Tabel 1

Penilaian Responden Berdasarkan Kategori Keadaan Fasilitas Sanitasi Taman Hutan Raya Ngurah Rai Provinsi Bali

\begin{tabular}{clccc}
\hline No & & Kategori & Jumlah (f) & Persentase (\%) \\
\hline 1 & Baik & 93 & 93,0 \\
2 & Tidak baik & 7 & 7,0 \\
\hline & Total & 100 & 100,0 \\
\hline
\end{tabular}

Tabel 2

Penilaian Responden Berdasarkan Kategori Kualitas Jasa Taman Hutan Raya Ngurah Rai Provinsin Bali

\begin{tabular}{|c|c|c|c|}
\hline No & Kategori & Jumlah (f) & Persentase (\%) \\
\hline 1 & Baik & 81 & $81 \%$ \\
\hline 2 & Tidak baik & 19 & $19 \%$ \\
\hline & Total & 100 & $100 \%$ \\
\hline
\end{tabular}

Tabel 3

Tingkat Kepuasan Pengunjung Taman Hutan Raya Ngurah Rai Provinsi Bali

\begin{tabular}{|c|c|c|c|}
\hline No & Kategori & Jumlah (f) & Persentase $(\%)$ \\
\hline 1 & Puas & 87 & $87 \%$ \\
\hline 2 & Tidak Puas & 13 & $13 \%$ \\
\hline & Total & 100 & $100 \%$ \\
\hline
\end{tabular}


Tabel 4

Hubungan Fasilitas Sanitasi Dengan Tingkat Kepuasan Pengunjung Taman Hutan Raya Ngurah Rai Provinsi Bali

\begin{tabular}{|c|c|c|c|c|c|c|}
\hline \multirow{2}{*}{$\begin{array}{l}\text { Fasilitas } \\
\text { Sanitasi }\end{array}$} & \multicolumn{2}{|c|}{ Kepuasan Pengunjung } & \multirow{2}{*}{ Jumlah } & \multirow{5}{*}{$\begin{array}{l}\text { Sig. } \\
0,045\end{array}$} & $\mathrm{CC}$ & $\begin{array}{c}\text { Tingkat } \\
\text { Hubungan }\end{array}$ \\
\hline & Puas & Tidak Puas & & & \multirow{4}{*}{$\mathbf{0 , 2 3 7}$} & \multirow{4}{*}{ Rendah } \\
\hline Baik & $\begin{array}{c}83 \\
(83,0 \%)\end{array}$ & $\begin{array}{c}10 \\
(10,0 \%)\end{array}$ & 93 & & & \\
\hline Tidak baik & $\begin{array}{c}4 \\
(4,0 \%)\end{array}$ & $\begin{array}{c}3 \\
(3,0 \%)\end{array}$ & 7 & & & \\
\hline Jumlah & 87 & 13 & 100 & & & \\
\hline
\end{tabular}

Tabel 5

Hubungan Kualitas Jasa Dengan Tingkat Kepuasan Pengunjung Taman Hutan Raya Ngurah Rai Provinsi Bali

\begin{tabular}{cccccccc}
\hline \multirow{2}{*}{$\begin{array}{c}\text { Kualitas } \\
\text { Jasa }\end{array}$} & \multicolumn{2}{c}{$\begin{array}{c}\text { Kepuasan } \\
\text { Pengunjung }\end{array}$} & & & CC & $\begin{array}{c}\text { Tingkat } \\
\text { Hubungan }\end{array}$ \\
\cline { 2 - 4 } & Puas & $\begin{array}{c}\text { Tidak } \\
\text { Puas }\end{array}$ & & & & \\
\hline Baik & 79 & 2 & & & & \\
& $(79,0 \%)$ & $(2,0 \%)$ & $(81,0 \%)$ & $\mathbf{0 , 0 0 0}$ & & $\mathbf{0 , 5 4 3}$ & Sedang \\
\cline { 2 - 4 } Tidak baik & 8 & 11 & 19 & & & \\
& $(8,0 \%)$ & $(11,0 \%)$ & $(19,0 \%)$ & & & \\
\hline Jumlah & 87 & 13 & 100 & & & \\
\hline
\end{tabular}




\section{Pembahasan}

\section{A. Keadaan Fasilitas Sanitasi}

Taman Hutan Raya Ngurah Rai

\section{Provinsi Bali}

Berdasarkan hasil penelitian yang telah dilakukan, dari 100 responden, 93 responden $(93,0 \%)$ yang menyatakan keadaan fasilitas sanitasi baik, dan sebanyak 7 responden $(7,0 \%)$ yang menyatakan tidak baik artinya sebagian besar responden memberi respon baik terhadap kaadaan fasilitas sanitasi di Taman Hutan Raya Ngurah Rai Provinsi yang dimana sudah menyediakan fasilitas sanitasi yang menurut pengunjung sebagian besar sudah baik, namun masih ada beberapa yang harus diperhatikan karena masih ada sekitar $(7,0 \%)$ pada kategori tidak baik

Keadaan fasilitas sanitasi penyediaan sarana air bersih, sebanyak 100 responden $(100 \%)$ menyatakan air jernih, air tidak berbau, dan tersedia air yang cukup. Berdasarkan wawancara dengan petugas, sebanyak 100 responden $(100,0 \%)$ menyatakan tidak tersedia washtafel.

Washtafel merupakan sarana sanitasi yang digunakan untuk mencuci tangan, tangan manusia seringkali menjadi agen membawa kuman dan menyebabkan pathogen berpindah dari satu orang atau dari alam ke orang lain melaui kontak langsung maupun tidak langsung (3). Apabila pengunjung megalami kesakitan yang didapatkan dari tempat wisata, maka dapat menurunkan kunjungan wisatawan dan citra destinasi wisata.

Dari keadaan fasilitas sanitasi toilet, sebanyak 100 responden $(100,0 \%)$ menyatakan tidak tersedia tempat sampah di toilet, sebanyak 41 responden $(41,0 \%)$ menyatakan toilet tidak bersih dan sebanyak 44 responden $(44,0 \%)$ menyatakan toilet pria dan wanita tidak terpisah

Adapun kriteria atau kelengkapan ruang toilet umum yang memenuhi syarat kesehatan yaitu harus tersedianya tempat sampah, dilengkapi sabun, terdapat simbol yang terlihat jelas untuk toilet wanita dan pria, tersedia tisuue, air bersih, pencahayaan yang mencukupi dan tersedia kloset duduk ataupun jongkok (4)

Dari keadaan fasilitas sanitasi keadaan tempat sampah, sebanyak 61 responden $(61,0 \%)$ menyatakan 
tempat sampah tidak mudah dijangkau dan sebanyak 68 responden $(68,0 \%)$ menyatakan tempat sampah tidak memiliki tutup. Wadah sampah yang baik yaitu tidak berat, mudah dikosongkan, alasnya tidak bocor, kokoh / kuat, tertutup dan sampahnya mudah dibawa sampai ke wadah sampah level-2 yaitu tempat penampungan sementara (TPS), bak sampah level-1 memiliki volume sampah 50 - 60 liter, wadah sampah / tong yang ada roda $120-140$ liter dengan jarak 20 meter antara wadah sampah/ tong yang satu dengan yang lainnya (5).

Gangguan yang timbul akibat sampah tidak dikelola dengan baik yaitu dapat menjadikan sumber pengotoran tanah, sumber air permukaan, air tanah maupun mencemari udara, menimbulkan bau yang tidak sedap, mengganggu keindahan lingkungan hidup (6)

Berdasarkan hasil penelitian, sebanyak 28 reponden $(28,0 \%)$ berpendapat saluran berbau dan 25 responden $(25,0 \%)$ berpendapat terdapat genangan air.

Pembuangan air limbah yang tidak saniter dapat menjadi media berkembang biaknya mikroorganisme pathogen, vektor dan binatang penganggu yang dapat menularkan penyakit kepada manusia. Beberapa hal yang bersifat umum pada saluran air kotor pada tempat pariwisata yang perlu diperhatikan yaitu tidak menimbulkan genangan air terutama untuk air hujan, saluran dapat mengalir dengan lancar, dan saluran pembuangan air kotor tertutup agar tidak menganggu estetika (7)

\section{B. Kualitas Jasa Taman Hutan Raya Ngurah Rai Provinsi Bali.}

Berdasarkan hasil penelitian, persepsi pengunjung mengenai kualitas jasa Taman Hutan Raya Ngurah Rai menunjukkan sebagian besar responden yaitu 81 responden $(81,0 \%)$ menyatakan kualitas jasa Taman Hutan Raya Ngurah Rai Provinsi Bali baik, sedangkan 19 responden $(19,0 \%)$ yang menyatakan kualitas jasa tidak baik

Dilihat dari dimensi bentuk fisik (tangible), sebanyak 40 responden $(40,0 \%)$ menyatakan tahura tidak tertata dengan bersih dan rapi, sebanyak 44 responden $(44,0 \%)$ menyatakan tidak tersedia papan informasi ataupun petunjuk arah. Sehingga petugas perlu melakukan 
perbaikan untuk mengubah persepsi pengunjung yang awalnya menjawab tidak tertata dan tidak bersedia menjadi tertata dan bersedia.

Dari dimensi kehandalan (reliability) sebanyak 41 responden $(41,0 \%)$ menyatakan pelayanan tidak sesuai dengan kebutuhan pengunjung. Kehandalan merupakan kemampuan memberikan layanan yang dijanjikan secara akurat, tepat waktu, dan dapat dipercaya. Memberikan pelayanan yang tidak sesuai dengan kebutuhan menyebabkan persepsi negatif terhadap kualitas jasa,

Dari dimensi ketanggapan (responsiveness) sebanyak 35 responden $(35,0 \%)$ menyatakan petugas tidak cepat dan tanggap dalam menyelesikan keluhan pengunjung. Membiarkan pelanggan menunggu tanpa alasan yang jelas, menyebabkan persepsi yang negatif dalam kualitas jasa, yang artinya bahwa pelayan atau petugas harus mampu memberikan pelayanan dengan baik seperti petugas siap kapan saja setiap pelanggan membutuhkan pelayanan.

Jaminan (anssurance) sebanyak 46 responden $(46,0 \%)$ merasa tidak aman dan nyaman berjalan di jalur tracking. Apabila jalur tracking dibiarkan dengan keadaan yang kurang baik seperti berlubang, goyang, dengan kemiringan tertentu dapat menimbulkan kecelakaan bagi pengunjung apabila tidak diperbaiki dengan cepat.

Dari dimensi perhatian (empaty) sebanyak 46 responden $(46,0 \%)$ menyatakan petugas tidak memberikan solusi terhadap masalah yang dihadapi oleh pengunjung.

Membiarkan suatu masalah tanpa diberikannya suatu jawaban solusi oleh petugas dapat menimbulkan persepsi negatif terhadap kualitas jasa sehingga, petugas harus memberikan pelayanan dengan tanpa melihat atau memandang status sosial pelanggan yang berkunjung, selain itu memberikan perhatian yang khusus saat berhadapan langsung dengan pelanggan (8)

\section{Tingkat Kepuasan Pengunjung Taman Hutan Raya Ngurah Rai \\ Provinsi Bali}

Berdasarkan hasil penelitian yang dilakukan menunjukkan bahwa sebagian besar responden yaitu 87 orang (87\%) merasa puas berkunjung ke Taman Hutan Raya Ngurah Rai 
Provinsi Bali, sedangkan 13 orang $(13,0 \%)$ merasa tidak puas berkunjung ke Taman Hutan Raya Ngurah Rai Provinsi Bali artinya sebagian besar responden memberikan respon baik yang dimana sudah memenuhi harapan pengunjung, namun ada $13,0 \%$ pada kategori tidak puas dikarenakan harapan pengunjung tidak tercapai, sehingga perlu perbaikan dari segi fasilitas sanitasi dan kualitas jasa Taman Hutan Raya Ngurah Rai Provinsi Bali agar pendapat konsumen berubah yang awalnya tidak puas menjadi menjadi puas saat berkunjung.

Berdasarkan hasil penelitian dari 100 responden sebanyak 13 orang $(13,0 \%)$ tidak bersedia membayar lebih besar untuk menjaga kelestarian dan keindahan Taman Hutan Raya Ngurah Rai Provinsi Bali dikarenakan pengunjung merasa kedaan objek wisata yang belum maksimal dalam memberikan pelayanannya dan dari fasilitasnya. Perasaan pengunjung yang merasa tidak puas hal ini termasuk wajar karena banyak yang dikorbankan oleh pengunjung saat melakukan rekreasi yaitu baik waktu, tenaga, maupun uang untuk mendapatkan sebuah produk atau layanan yang baik.

\section{Hubungan Fasilitas Sanitasi}

\section{Dengan Tingkat Kepuasan}

\section{Pengunjung Tahura Ngurah Rai}

Dari uji chi- square di dapatkan sig $=0,045<0,05$ hal ini menunjukkan ada hubungan yang signifikan antara keadaan fasilitas sanitasi dengan tingkat kepuasan pengunjung Taman Hutan Raya Ngurah Rai Provinsi Bali dengan Coefficient Contingency $\mathrm{CC}=0,273$ yang artinya ada hubungan namun masih dikategorikan rendah.

Hal ini menunjukkan bahwa masih terdapat pengunjung yang merasa tidak puas berkunjung ke Taman Hutan Raya Ngurah Rai Provinsi Bali yang disebabkan pengunjung merespon keadaan fasilitasi sanitasi Taman Hutan Raya Ngurah Rai Provinsi Bali tidak baik.

Semakin baik fasiltas yang diberikan maka semakin tinggi kepuasan yang dirasakan pengunjung, sebaliknya semakin buruk keadaan fasilitas maka semakin rendah kepuasan yang dirasakan pengunjung (9). 


\section{E. Hubungan Kualitas Jasa Dengan} Tingkat Kepuasan Pengunjung Tahura Ngurah Rai Provinsi

\section{Bali}

Dari uji Chi-Square di dapatkan sig $=0,000<0,05$ hal ini menunjukkan ada hubungan kualitas jasa dengan tingkat kepuasan pengunjung Taman Hutan Raya Ngurah Rai Provinsi Bali dengan Coefficient Contingency $\mathrm{CC}=0,543$ yang artinya ada hubungan namun masih dikategorikan sedang.

Hal ini menunjukkan bahwa masih terdapat pengunjung yang merasa tidak puas berkunjung ke Taman Hutan Raya Ngurah Rai Provinsi Bali yang disebabkan pengunjung merespon kualitas jasa Taman Hutan Raya Ngurah Rai Provinsi Bali tidak baik.

Semakin tinggi nilai yang dirasakan pengunjung maka semakin besar kepuasan yang dirasakan pengunjung, sebaliknya Semakin rendah nilai yang dirasakan pengunjung maka semakin kecil kepuasan yang dirasakan pengunjung (9).

\section{Simpulan}

Keadaan fasilitas sanitasi Taman Hutan Raya Ngurah Rai Provinsi Bali dapat dikatakan belum berjalan dengan maksimal karena masih ada persepsi pengunjung yang menyatakan keadaan fasilitas sanitasi tidak baik yaitu sebanyak 7 responden (7\%) dan sebanyak 93 responden (93\%) menyatakan fasilitas sanitasi baik,

Kualitas jasa Taman Hutan Raya Ngurah Rai Provinsi Bali dapat dikatakan belum berjalan dengan maksimal karena masih ada persepsi pengunjung yang menyatakan kualitas jasa Taman Hutan Raya Ngurah Rai Provinsi Bali tidak baik sebanyak 19 responden (19\%) dan sebanyak 81 responden (81\%) yang menyatakan baik,

Tingkat kepuasan pengunjung yang merasa puas berkunjung ke Taman Hutan Raya Ngurah Rai Provinsi Bali sebanyak 87 responden (87\%) dan sebanyak 13 responden $(13 \%)$ merasa tidak puas

Ada hubungan yang signifikan antara keadaan fasilitas sanitasi dengan tingkat kepuasan pengunjung Taman Hutan Raya Ngurah Rai 
Provinsi Bali dengan tingkat hubungan rendah,

Ada hubungan yang signifikan antara kualitas jasa dengan tingkat kepuasan pengunjung Taman Hutan Raya Ngurah Rai Provinsi Bali dengan tingkat hubungan sedang.

\section{Saran}

Untuk pihak pengelola Taman Hutan Raya Ngurah Rai Provinsi Bali perlu melakukan upaya peningkatan sarana prasarana baik dari segi fasilitas sanitasi, fasiltas umum dan kualitas pelayanan

Bagi peneliti selanjutnya, agar menggunakan kuesioner model skala likert dengan 4 kategori agar tidak mengalami kesulitan padaa saat mengelompokkan kategori.

\section{Daftar Pustaka}

1. Pastin M. Tingkat Kepuasan

Masyarakat Terhadap Kualitas

Jasa Taman Hutan Raya

Ngurah Rai Provinsi Bali.

Universitas Mahasaraswati; 2014.

2. Sugiyono. Metode Penelitian Kuantitatif, Kualitatif dan R \& D. Bandung: Penerbit Alfabeta; 2012.
3. Silviana I. Perilaku Cuci Tangan Pakai Sabun Studi Kualitatif pada Ibu-Ibu di Kampung Nelayan Muara angke Jakarta Utara. arkemas. 2017;2.

4. Meldika. Pedoman Standar Toilet Umum Indonesia. Indonesia; 2016.

5. Ichan,Sri Muryani S. Sanitasi Transportasi, Pariwisata dan Matra. Jakarta: Kementerian Kesehatan Republik Indonesia; 2018.

6. Suparlan. Pengantar Pengawasan Sanitasi Tempat tempat Umum - Wisata \& Usaha - usaha untuk Umum. Surabaya: Percetakan

Duatujuh; 2012.

7. Saputra J. Studi Deskriptif Sanitasi Kantin Dan Fasilitas Sanitasi Dasar Di Lingkungan Sekolah Dasar Pada Wilayah Kerja Puskesmas Ungaran Kecamatan Ungaran Barat, Kabupaten Semarang Tahun 2016. Universitas Negeri

Semarang; 2016.

8. Nur Jayanti D. Kualitas

Pelayanan (Reliability, Responsiveness, Assurance, 
Emphaty, Tangibles)Di Legend

Premium Coffee Yogyakarta.

Universitas Negeri

Yogyakarta; 2014.

9. Clara Lintang A. Pengaruh

Kualitas Pelayanan dan

Fasilitas Terhadap Kepuasan
Pengunjung. Studi kasus

Pengunjung The Sila's

Agrotourism Br. Batusesa,

Desa Candikuning, Kecamatan

Baturiti, Kabupaten Tabanan,

Provinsi Bali. Universitas

Sanata Dharma; 2017. 